\title{
Study on the Life Characteristics of a Flowering Plant in a Harsh Environment
}

\author{
Jingpeng Yan \\ The Academic Committee of China Academy of Management Science, Beijing, 100036, China. \\ Scientific Research Publishing Committee of Chinese Medical Doctor Association, Beijing, 100073, China. \\ International Journal of Clinical Research, Changsha, Hunan Province, 410000, China. \\ College of Physical Science and Technology, Jishou University, Jishou, Hunan Province, 416000, China. \\ Qingpeng International Science Exploration Center, Changsha, Hunan Province, 410000, China.
}

How to cite this paper: Jingpeng Yan. (2020) Study on the Life Characteristics of a Flowering Plant in a Harsh Environment. Journal of Humanities, Arts and Social Science, 4(2), 112-117.

DOI: 10.26855/jhass.2020.07.005

Received: August 18, 2020

Accepted: September 10, 2020

Published: September 17, 2020

${ }^{*}$ Corresponding author: Jingpeng Yan, The Academic Committee of China Academy of Management Science, Beijing, 100036, China; Scientific Research Publishing Committee of Chinese Medical Doctor Association, Beijing, 100073, China; International Journal of Clinical Research, Changsha, Hunan Province, 410000, China; College of Physical Science and Technology, Jishou University, Jishou, Hunan Province, 416000, China; Qingpeng International Science Exploration Center, Changsha, Hunan Province, 410000, China.

\begin{abstract}
Aims: This study researched on drought resistance characteristics of the flowering plant in harsh environments; Methods: It observed the growth of the flowering plant in harsh environments constantly for one month; Findings: The plant grows well in harsh environments; Conclusion: This flowering plant can be used in scenarios such as greening, drought resistance, water and moisture conservation, ecological transformation, and so on, which has high and comprehensive value.
\end{abstract}

\section{Keywords}

Flowering Plant, Drought Resistance, Environment, Ecological Transformation

\section{Introduction}

On July 6, 2020, the author drove by Jinxing Middle Road, Yuelu District, Changsha City, Hunan Province, and found a flowering plant at the central fence of the road at the intersection of Jinxing Middle Road and Hanguang Road, which grew at the screw hole that connects the fifth enclosure to the ground. Not many small holes are on the ground, nor obvious earth is found on the surface, because it is an asphalt road. This plant attracted the author's attention, he decided to follow it for a long time to learn its life characteristics (Figure 1).

\section{Materials and Methods}

The section where this plant grows is located at Jinxing Road. This road is a conventional asphalt pavement. The central barrier of the pavement is made of steel and no obvious soil is on the pavement. And Changsha is known as a 
stove city, which summer is dominated by high temperature and less rain. The average temperature of its summer is 35 degrees. After the steel fence is exposed to the sun, its temperature rises. It is difficult to store water and nutrients in such environment (Figures 2-4).

After consulting, the plant was not found to have a written name, so the author named it Yanchen Grass, which represents a herb plant that survives in a hot environment.

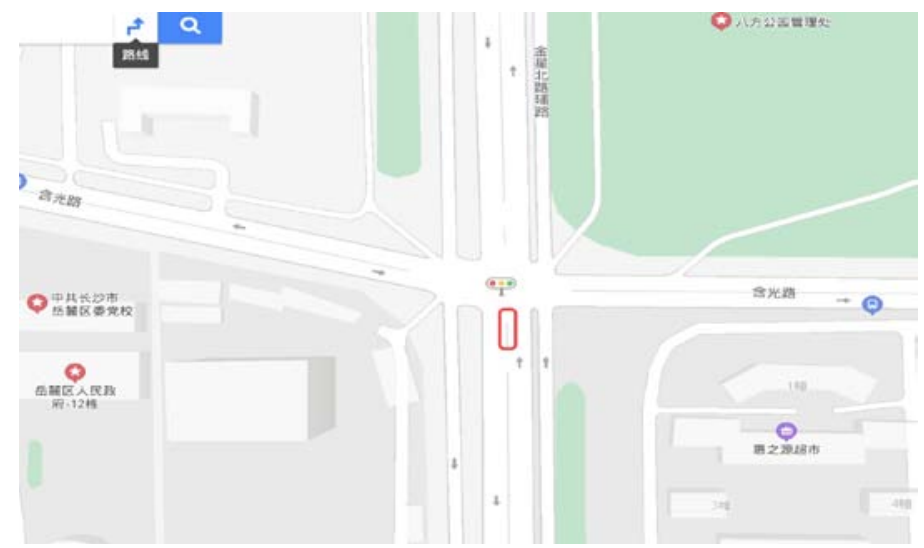

Figure 1. The place marked in red is where the plant grows (data from Baidu Map).

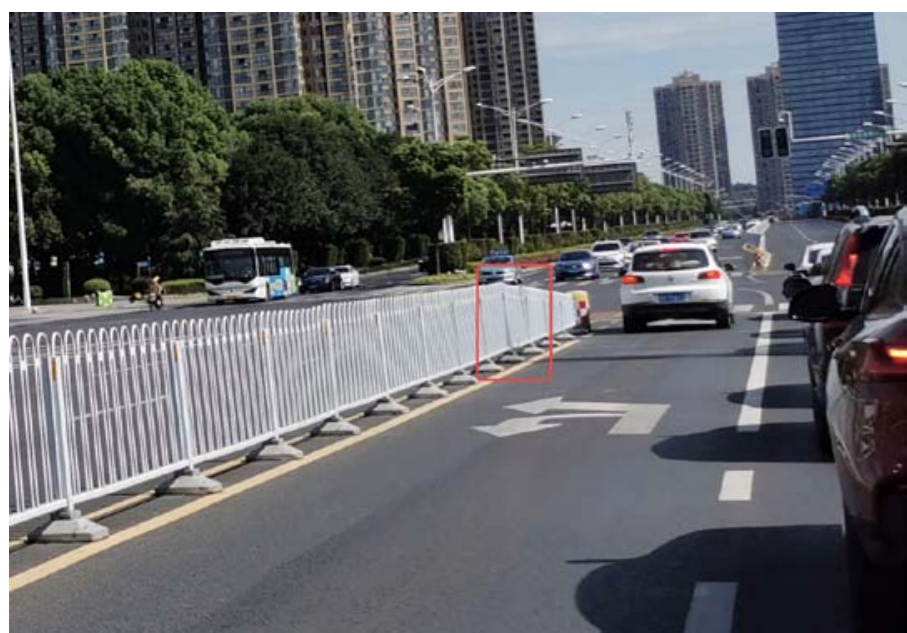

Figure 2. The location and the range where it grows (photo taken on the spot).

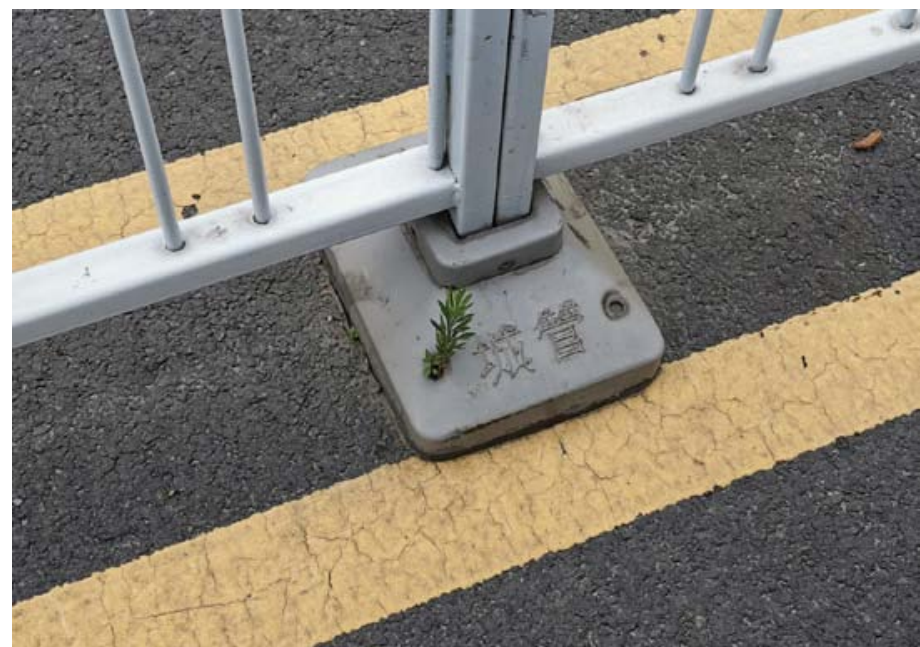

Figure 3. The specific location where it grows (photo taken on the spot). 


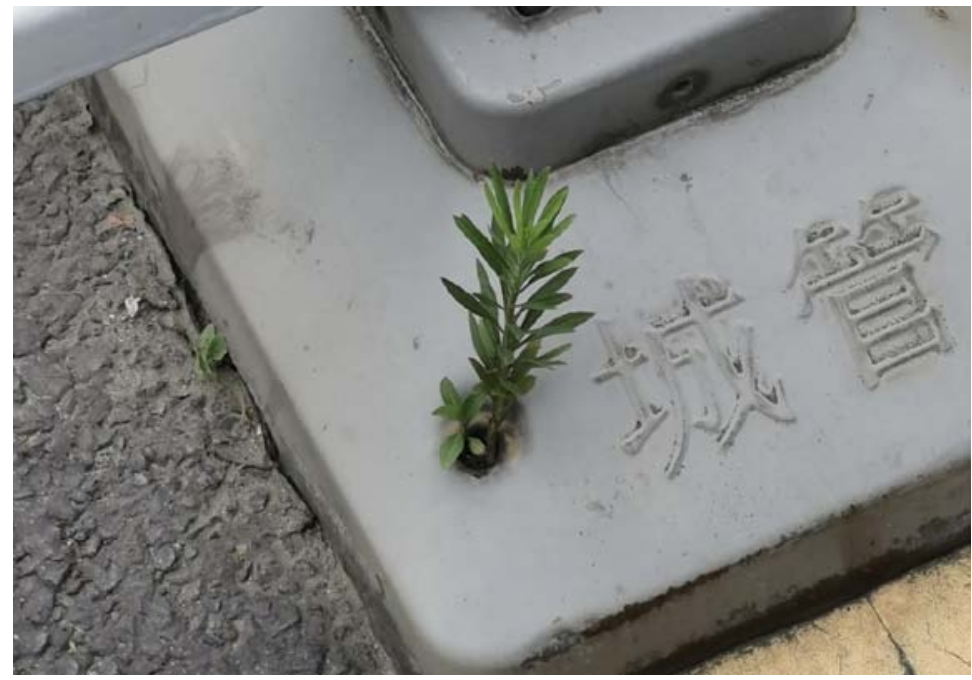

Figure 4. Close-up of the location where it grows (photo taken on the spot).

The author observed and photographed the plant on July 6, July 15, July 28, August 7, August 22, and August 30, 2020, and found that it survived and was in good condition.

The weather from July 6 to July 31 was mainly sunny and dominated by high temperature (The China Weather Network, 2020), as shown in the chart below (Figure 5).

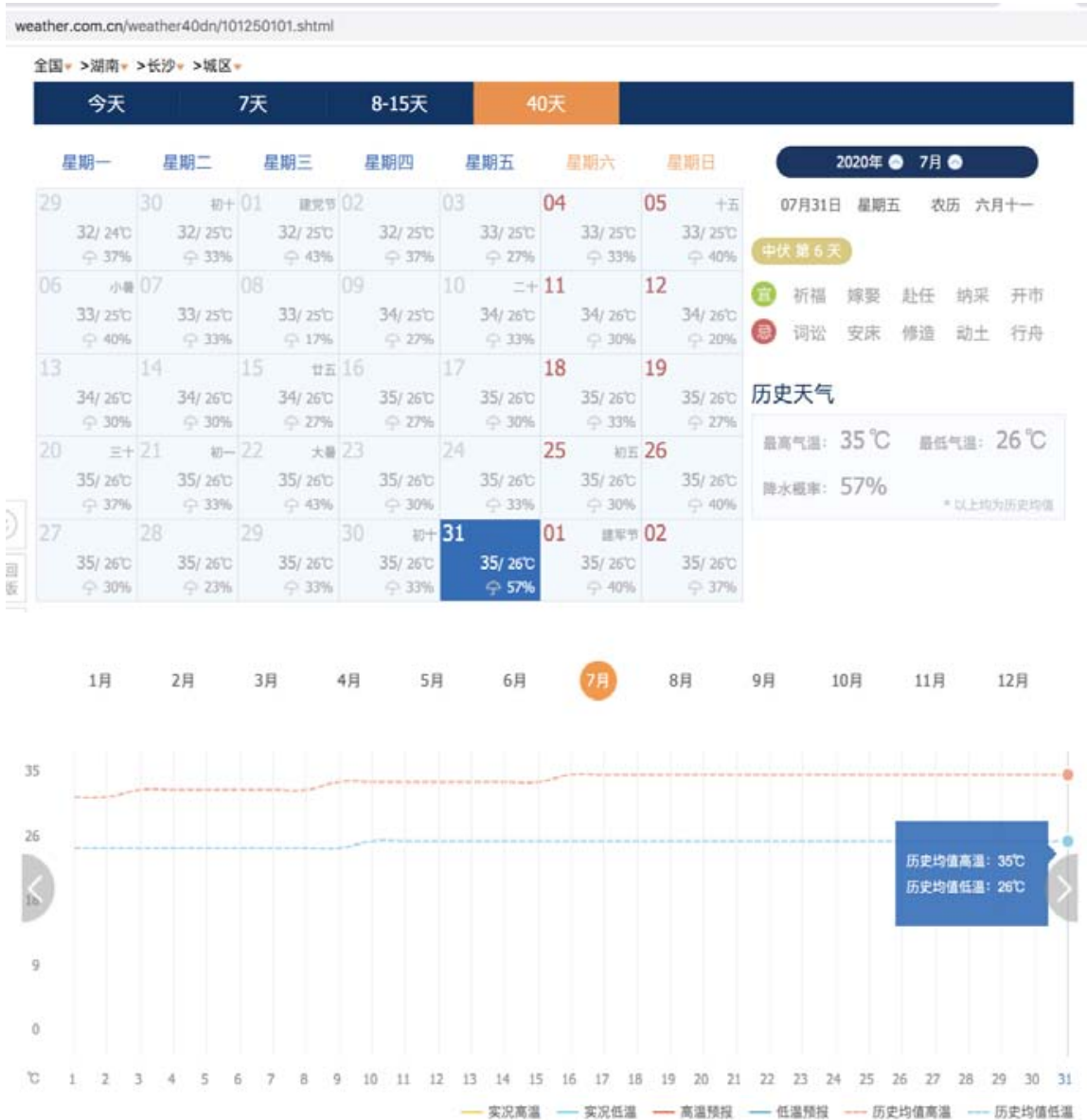

Figure 5. The screenshot of the weather and temperature in July (Data sources: China Weather Network). 
weather.com.cn/weather40dn/101250101.shtml

全国 $v>$ 湖南 $v>$ 长沙 $v>$ 城区

18:00更新 数据来源 中央气象台

\section{今天}

7天

8-15天

40 天

\begin{tabular}{|c|c|c|c|c|c|c|c|}
\hline 星期一 & 星期二 & 星期三 & 星期四 & 星期五 & 星期六 & 星期日 & 2020年 ○8月 8 \\
\hline 27 & 28 & 29 & 30 & 31 & 建军节 & 02 & 08月18日＼cjkstart星期二 \\
\hline $35 / 26^{\circ} \mathrm{C}$ & $35 / 26^{\circ} \mathrm{C}$ & $35 / 26^{\circ} \mathrm{C}$ & $35 / 26^{\circ} \mathrm{C}$ & $35 / 26^{\circ} \mathrm{C}$ & $35 / 26^{\circ} \mathrm{C}$ & $35 / 26^{\circ} \mathrm{C}$ & \\
\hline $30 \%$ & $23 \%$ & $33 \%$ & $33 \%$ & $57 \%$ & $40 \%$ & $37 \%$ & 材第 4 天 \\
\hline 03 & 04 & 05 & 06 & 立秋 & 08 & $=+$ & 宜 斋醮 祈福 \\
\hline $34 / 26^{\circ} \mathrm{C}$ & $34 / 26^{\circ} \mathrm{C}$ & $34 / 26^{\circ} \mathrm{C}$ & $34 / 26^{\circ} \mathrm{C}$ & $34 / 26^{\circ} \mathrm{C}$ & $34 / 26^{\circ} \mathrm{C}$ & $34 / 26^{\circ} \mathrm{C}$ & \\
\hline $37 \%$ & $30 \%$ & $33 \%$ & $30 \%$ & $33 \%$ & $30 \%$ & $30 \%$ & 入王 \\
\hline 10 & 11 & 12 & 13 & 14 & 15 & 16 & \\
\hline $34 / 26^{\circ} \mathrm{C}$ & $34 / 25^{\circ} \mathrm{C}$ & $34 / 25^{\circ} \mathrm{C}$ & $34 / 25^{\circ} \mathrm{C}$ & $33 / 25^{\circ} \mathrm{C}$ & $33 / 25^{\circ} \mathrm{C}$ & $36 / 24^{\circ} \mathrm{C}$ & 实况天气 \\
\hline $23 \%$ & $27 \%$ & $37 \%$ & ๑ $43 \%$ & $50 \%$ & $40 \%$ & $03 \mathrm{~mm}$ & \\
\hline 17 & 18 & 初- & 20 & 21 & 处暑 & 23 初五 & 气温： \\
\hline $36 / 25^{\circ} \mathrm{C}$ & $37 / 26^{\circ} \mathrm{C}$ & $36 / 26^{\circ} \mathrm{C}$ & $36 / 26^{\circ} \mathrm{C}$ & $34^{\circ} \mathrm{C}$ & A $33^{\circ} \mathrm{C}$ & $36^{\circ} \mathrm{C}$ & 隆水量: $1 \mathrm{~mm}$ \\
\hline $5 \mathrm{~mm}$ & $01 \mathrm{~mm}$ & $00 \mathrm{~mm}$ & $0 \mathrm{~mm}$ & $\mathrm{~A} 25^{\circ} \mathrm{C}$ & $\triangle 25^{\circ} \mathrm{C}$ & $227^{\circ} \mathrm{C}$ & \\
\hline 24 & 25 七夕部 & 26 & 27 & 28 初十 & 29 & 30 & \\
\hline$\therefore 36^{\circ} \mathrm{C}$ & $-35^{\circ} \mathrm{C}$ & $-34^{\circ} \mathrm{C}$ & $\therefore 32^{\circ} \mathrm{C}$ & $33^{\circ} \mathrm{C}$ & $=33^{\circ} \mathrm{C}$ & .. $31^{\circ} \mathrm{C}$ & \\
\hline$\angle 26^{\circ} \mathrm{C}$ & $.23^{\circ} \mathrm{C}$ & $\therefore 24^{\circ} \mathrm{C}$ & $25^{\circ} \mathrm{C}$ & $23^{\circ} \mathrm{C}$ & $.24^{\circ} \mathrm{C}$ & $24^{\circ} \mathrm{C}$ & \\
\hline 31 & 01 & 02 中元节 & 03 抗日纪念日 & 04 & 05 & 06 & \\
\hline $\begin{array}{l}32^{\circ} \mathrm{C} \\
23^{\circ} \mathrm{C}\end{array}$ & $\begin{array}{l}39^{\circ} \mathrm{C} \\
23^{\circ} \mathrm{C}\end{array}$ & $\begin{array}{l}30^{\circ} \mathrm{C} \\
23^{\circ} \mathrm{C}\end{array}$ & $\begin{array}{r}\quad 33^{\circ} \mathrm{C} \\
=24^{\circ} \mathrm{C}\end{array}$ & $\begin{array}{l}33^{\circ} \mathrm{C} \\
24^{\circ} \mathrm{C}\end{array}$ & ${ }_{24^{\circ} \mathrm{C}}^{31^{\circ} \mathrm{C}}$ & $S_{24^{\circ} \mathrm{C}}^{31^{\circ} \mathrm{C}}$ & \\
\hline
\end{tabular}

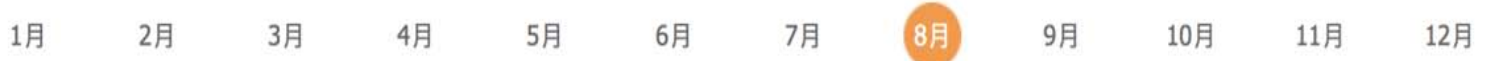

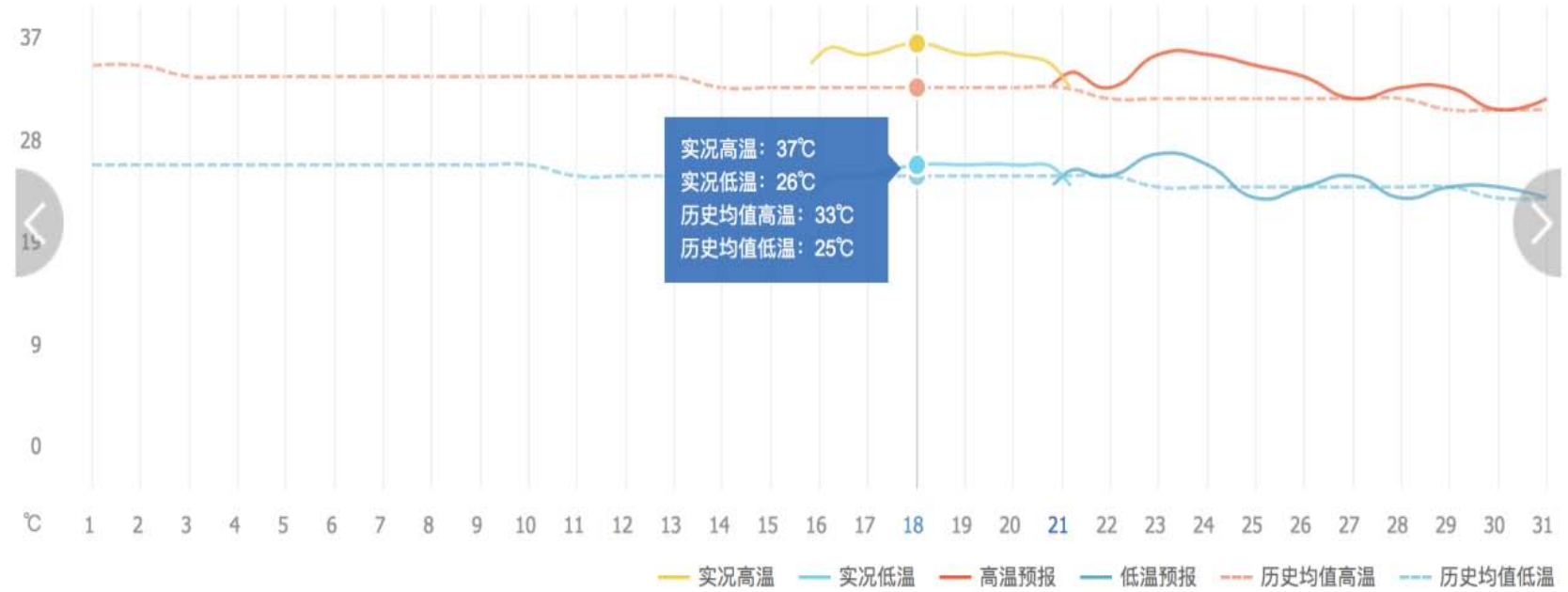

Figure 6. The screenshot of the weather and temperature in August (Data sources: China Weather Network).

The fence is made of steel. After it is exposed to high temperature, its temperature can reach more than 50 degrees. In such condition, the growth chart of the plant is as follows (Figure 7a-7f): 


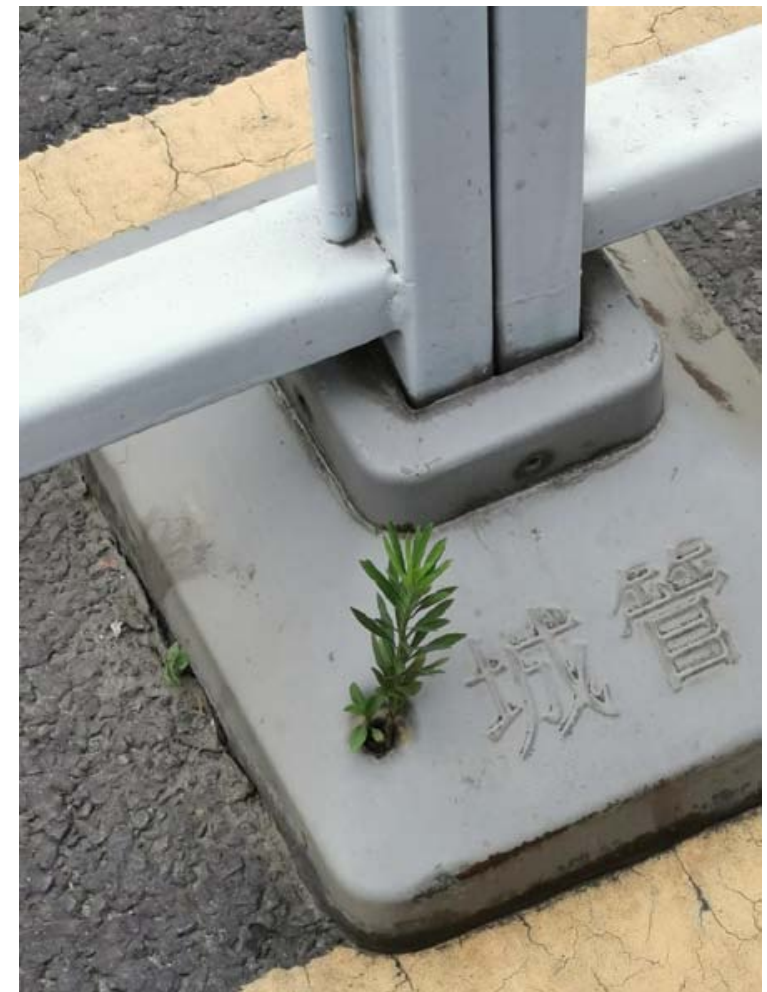

Figure 7a. The growth chart shot at 2:18 PM on July 6.

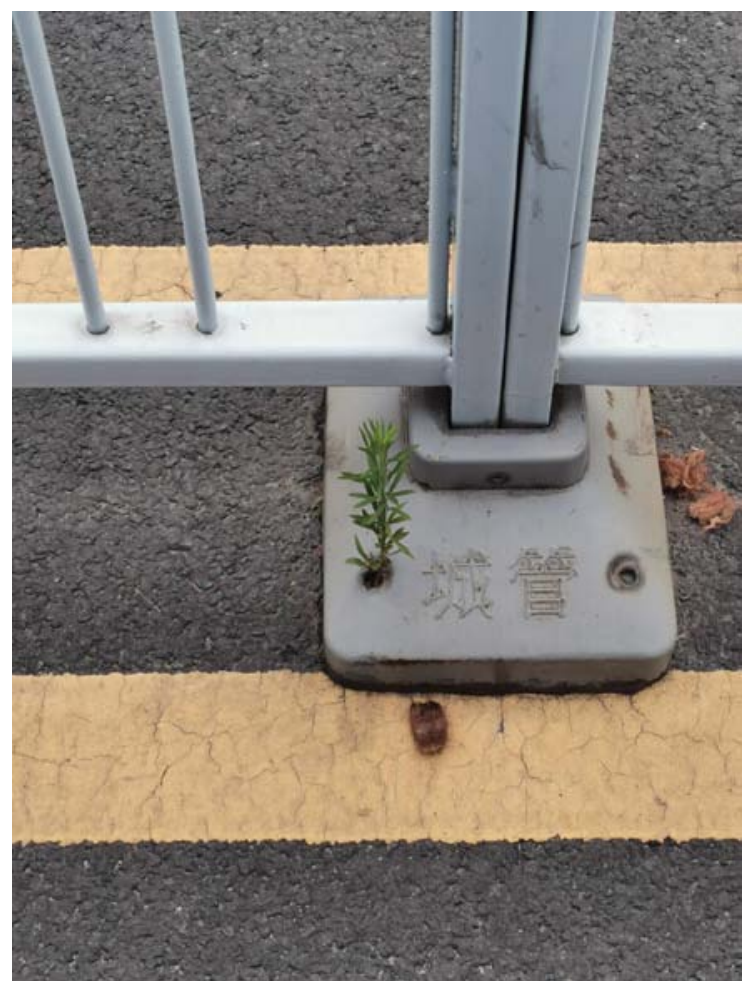

Figure 7c. The growth chart shot at 3:24 PM on July 28.

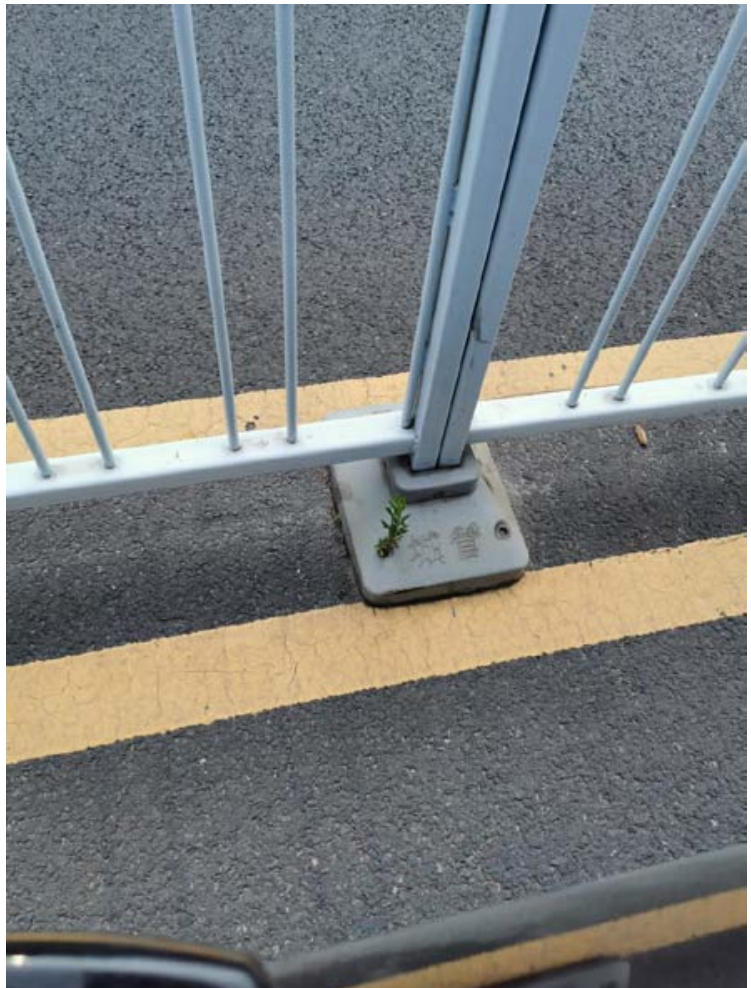

Figure 7b. The growth chart shot at 3:02 PM on July 15.

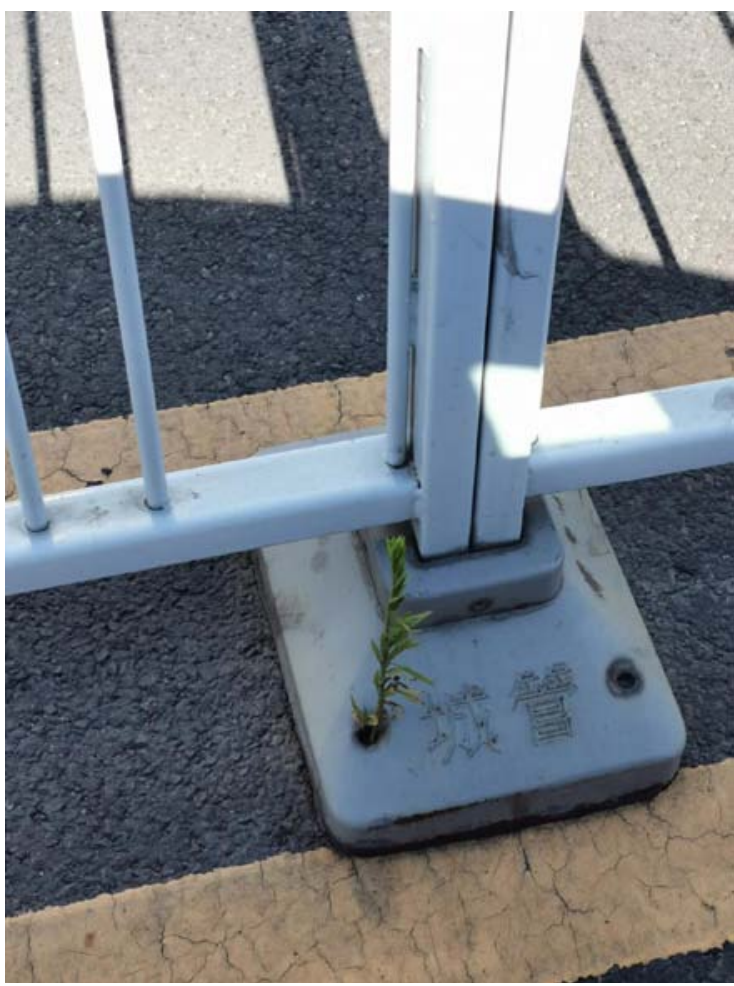

Figure 7d. The growth chart shot at 9:12 AM on August 7. 


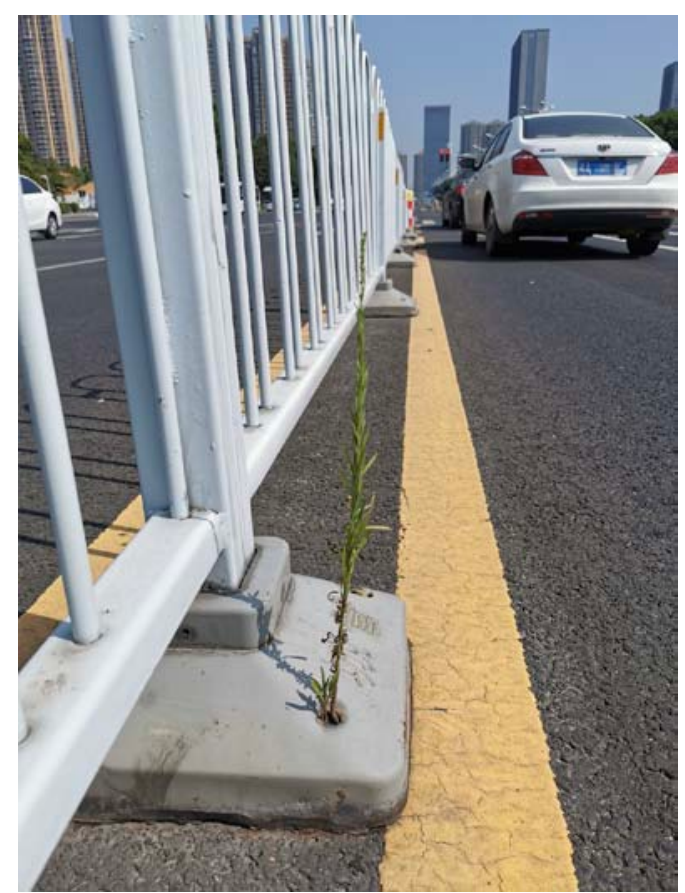

Figure 7e. The growth chart shot at 11:04 AM on August 22.

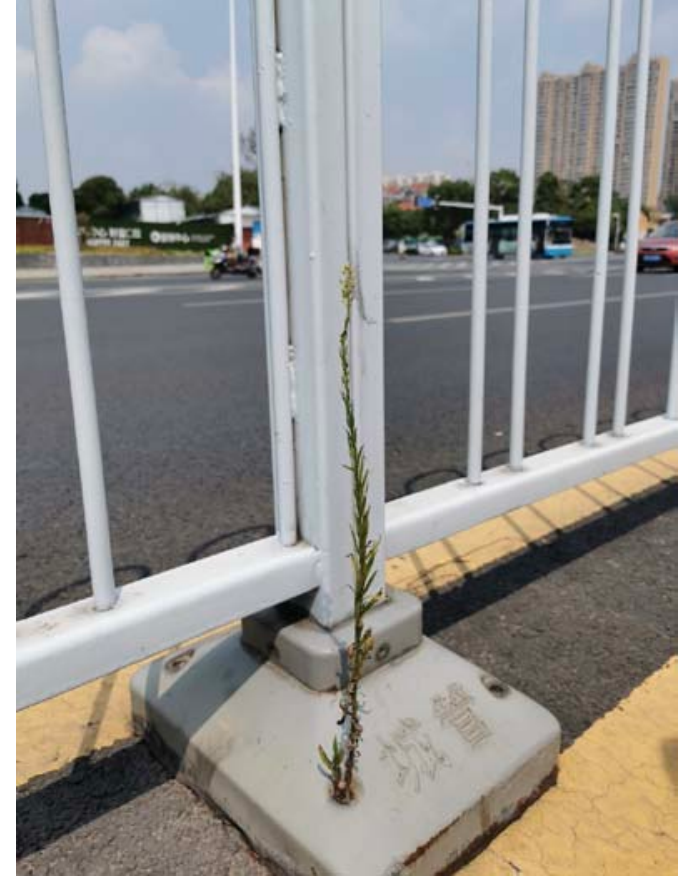

Figure 7f. The growth chart shot at 10:50 AM on August 30.

After 54 days of observation, Yanchen Grass survived in the steel fence on the asphalt road. It kept growing in such a harsh environment where there was no obvious soil, the weather was constantly dominated by high temperature, and there was less rain. Not only did the plant survive, but its height increased by about 5 times. It was ready to bloom and bear fruit, showing its tenacious vitality.

\section{Conclusion}

The study found that under the high-emission scenario, by the end of the 21st century, the area of arid and semi-arid areas has increased by 23\%, compared with the area of that from 1961 to 1990 (Huang et al., 2016), accounting for more than $50 \%$ of the world's land surface and threatening the living space of mankind. Yanchen Grass is drought-resistant, high-temperature resistant, water-saving, and has a wide range of uses. It can be widely used in arid land management, water and moisture conservation, urban green belts, green buildings and other scenarios (Linda Chalker-Scott, 2007). It has high ecological and social value and is worthy of research and promotion (Zhao et al., 2017; Mohamed, 2009; Nair \& Padmavathy, 2014; Boyda \& McClelland, 1999).

\section{References}

China Weather Network. (2020). data of the weather from July to August in 2020, http://www.weather.com.cn/weather40dn/101250101.shtml.

Huang J., H. Yu, X. Guan, et al. (2016). Accelerated dryland expansion under climate change. Nature Climate Change, 6(2), 166-172. DOI: 10.1038/nclimate2837.

Linda Chalker-Scott. (2007). Impact of Mulches on Landscape Plants and the Environment-A Review. Journal of Environmental Horticulture, 25(4): 239-249.

D. F. Zhao, A. Buchholz, E. Kleist, et al. (2017). Environmental conditions regulate the impact of plants on cloud formation. Nature Communications, Volume 8.

Khaled A. Mohamed. (2009). Environmental Impact of Desalination Plants on the Environment. Thirteenth International Water Technology Conference, IWTC 13 2009, Hurghada, Egypt.

Dhanya N. Nair and S. Padmavathy. (2014). Impact of Endophytic Microorganisms on Plants, Environment and Humans. The Scientific World Journal.

Gale A. Boyda, John D. McClelland. (1999). The Impact of Environmental Constraints on Productivity Improvement in Integrated Paper Plants. Journal of Environmental Economics and Management, 38(2), 121-142. 